\title{
"Eating is an Agricultural Act": longing for the good life
}

\author{
Maria Teresa Lobo Castilho \\ CETAPS / Universidade do Porto
}

\begin{abstract}
In "The Pleasures of Eating”, Wendell Berry, a writer, poet, essayist and New Agrarian cultural critic, points out the importance of understanding the connection between food and the land, observing that "eating is an agricultural act". This statement takes us back to 1930, when a group of intellectuals from Vanderbilt University expressed their indignation against northern industrialism and their firm belief in "an honorable peace with nature" as the basis for a good and happy life in an organized healthy and well-structured agrarian society. Berry himself has taken on this responsibility by establishing a small farm near Port Royal, Kentucky, and by sustainably working his land and writing his texts for about five decades, problematizing the importance of understanding the connection between food and land as unquestionable bases for a good life. Berry, as he himself acknowledges, is heir to some of the principles of the Agrarians of I'll Take My Stand, and is one of the key figures in the New Agrarian Movement in American Culture, which fiercely opposes the degradation of a sustainable and healthy way of life. In his introduction to Berry's Bringing It to the Table: On Farming and Food, Michael Pollan, one of the most active proponents of the food reform in the United States, stresses the great relevance of this writer, who, in spite of not being directly committed to a particular food movement, is someone who has inspired the rise of Food and Slow Food Movements in the United States. Actually Berry is known to many as a great inspiring reference to sustainable food movements in the United States, having thus greatly contributed to the many Food Studies programs in American higher-education institutions which started to crop up in the period around the 1990s. Nevertheless, Berry's work and thought can be truly understood and appreciated only if we recognise the undeniable utopianism which has been feeding his hopeful prospect of an organized and well-structured agrarian society, where all might eat sustainably. As a matter of fact, if the connection between healthy and sustainable food and sustainable land
\end{abstract}


was already degraded in 1989, as Berry fiercely denounced in "The Pleasures of Eating", what then to say in 2017 ? To this question Wendell Berry enthusiastically keeps answering that hope is a virtue.

Keywords: Wendell Berry, "good life", Agrarianism/ Industrialism, Food Studies, Michael Pollan

Resumo: Em "The Pleasures of Eating", Wendell Berry, escritor americano, poeta e ensaísta e uma das figuraschave do recente "New Agrarian Movement", tem defendido a importância de compreender a conexão entre a alimentação e a agricultura, observando que "eating is an agricultural act". Esta afirmação conduz-nos a 1930 e ao grupo dos Agrários, intelectuais sulistas da Universidade de Vanderbilt, que expressaram a sua indignação contra o processo de industrialização que o Norte Yankee estava a impor na sua região. É perante o sublinhar da premência do respeito pela terra arável como base para uma vida boa e feliz que o próprio escritor reconhece ser uma espécie de herdeiro de muitos dos princípios defendidos pelos Agrários de I'll Take My Stand. 0 próprio Wendell Berry assumiu essa responsabilidade estabelecendo uma pequena quinta perto de Port Royal, no Kentucky. Aí Berry tem trabalhado de forma sustentável a sua terra arável e tem escrito contra a degradação de uma vida saudável, defendendo, há cerca de cinco décadas, a importância de entender a inquestionável relação que urge haver entre a produção dos alimentos e a agricultura que praticamos, como base inquestionável para alcançar uma vida boa. Na sua introdução ao livro de Wendell Berry intitulado Bringing It to the Table: On Farming and Food, publicado em 2009, Michael Pollan, um dos mais ativos defensores de uma reforma alimentar nos Estados Unidos, sublinha a grande relevância do escritor para os Estudos sobre Alimentação no contexto americano. Apesar de Wendell Berry não integrar ativa e diretamente qualquer movimento ligado a essa área de estudos, o escritor tem sido, na verdade, considerado uma importante referência inspiradora para movimentos sobre a alimentação saudável nos Estados Unidos. De facto, na globalidade da sua escrita e das suas intervenções em entrevistas e conferências, Berry, ao denunciar a intervenção da industrialização na agricultura, tem sublinhado as consequentes más práticas alimentares e os seus perigos. Deste modo, com as suas chamadas de atenção, este escritor e intelectual sulista muito tem contribuído para a pertinência e desenvolvimento de programas de Estudos sobre a Alimentação em instituições americanas de ensino superior, que nos Estados Unidos começaram a surgir por volta anos de 1990. Porém, o trabalho e o pensamento de Berry só podem ser verdadeiramente compreendidos e apreciados se reconhecermos o inegável utopismo que vem alimentando a sua esperança em torno de uma possível futura sociedade agrária organizada e bem estruturada, onde todos possam comer de forma saudável e sustentável. É que se uma boa relação entre alimentação e o trabalho da terra arável já estava degrada em 1989, como Berry denunciou em "The Pleasures of Eating", o que dizer, então, em 2017? A esta pergunta Wendell Berry com entusiasmo continua a responder que a esperança é uma virtude.

Palavras-chave: Wendell Berry, "vida boa", Agrarianismo/ Industrialização, Estudos sobre Alimentação, Michael Pollan 
While the South seemed to embrace its modernization and industrialization wholeheartedly in 1915, a group of Southern intellectuals founded a movement to defend agrarian values against the then prevailing urban and industrial ones. In their essays the by then so-called Fugitives voiced their fears and openly rejected the prevalent denial of national agrarian tradition, thus becoming a kind of mentors of The Agrarians, harking back to the Jeffersonian founding principles "of America, free from England, as a boundless Utopia of farms taking a thousand generations to fill" (Ransom et alii 1977: 69-70). At the time, the nation's pastoral and agrarian roots dating back to the country's founding were being replaced by the strong winds of mechanization and industrialization, which at the turn of the century were beginning to blow also in the South. As Paul Conkin reminds us, "[i]n a sense the origins of Southern Agrarianism stretch back to about 1915. By then, a halfdozen young men in Nashville, Tennessee, most either students or faculty professors at Vanderbilt University, began gathering periodically for some heavy philosophical discussions. After the war those few, joined by an equal number of younger men, switched their concern to poetry and for four years published a small monthly journal, The Fugitive. After 1925, four of these Fugitives soon joined by friends or colleagues, turned their attention to political and economic issues, and particularly to the problems of the South. These discussions first found an outlet in what became a famous book, I'll Take My Stand, and in a crusade called Southern Agrarianism" (Conkin 1988: 1).

In I'll Take My Stand the twelve Southern Agrarians intellectuals and poets embodied their indignation towards the changes imposed by the process of Americanization and its high capitalist economy, materialism and industrialism in the first decades of the $20^{\text {th }}$ century. They sought to confront the widespread and rapidly increasing effects of modernity, urbanism, industrialism and a new money economy in the country and, above all, in the culture and tradition of the South. These intellectuals did not believe in the optimistic notion of continual progress based on industrialism offered by their contemporaries and, on the contrary, predicted our current dilemma or, in John Crowe Ransom's words, "what is called progress is often destruction" (Ransom 1934: 310). Ultimately, these intellectuals connected to Vanderbilt University in Nashville, Tennessee, 
bemoaned the increasing loss of Southern identity and traditional culture to the Northern model of progress, modernity, and industrialism.

Undoubtedly agrarianism is inherently conservative and, in the past, one of the problems with this Southern movement was that it upheld a Southern way of life which was a core part of the American cultural mechanism responsible for both racism and cultural and social elitism. However, and according to a more recent reassessment of the Nashville Agrarians' work and thought, and which in some details contradicts its first negative reception, the current understanding of their manifesto of political, cultural and economic conceptions points out that one of their main goals was also to articulate a philosophy rooted in love and respect for the land with the enormous changes the traditional rural South was undergoing. Indeed, they were trying to reformulate a regionalist impulse and at the same time to promote the distinctive traditional Southern values along with agrarian principles and a healthy way of life. They affirmed their convictions and values as a decisive alternative to modern urban life and industrialism, which the Yankees were blindly advocating, unaware that such progress, as The Southern Agrarians stressed, would sooner or later become dystopia itself. Above all, moved by their preoccupation with life in the South and in the country as a whole, they identified themselves as the spokesmen for the founding American principles they believed in.

As Eric Freyfogle, the editor of The New Agrarianism: Land, Culture and the Community of Life, published in 2001, states in his stimulating introduction entitled "A Durable Scale", "collectively, the [Agrarians of I'll Take My Stand] expressed alarm over the effects of industrialism and materialism on the mannerly, leisurely, humanistic culture they viewed as the South's greatest treasure" (Freyfogle 2001: XXXVIII). These old Nashville Agrarians were in fact involved in a process of rejection of the integration of their region into the modern social and economic dominant American model, which, in those days, promoted the view of a never-ending progress brought by post-First World War technology and industry.

The Agrarians of the Thirties focused on their beloved Southern region and, in their writings, advocated a rural South devoted to farms, crops, and animals, against the then 
modern Yankee North with its high capitalist finance and industrialization. As highlighted by Eric Freyfogle, who quotes John Crowe Ransom in I'll Take My Stand, "[for the Agrarians] industrialism 'was the latest form of pioneering and the worst,' its driving energy the "principle of boundless aggression against nature.'" "Although," Freyfogle goes on, "[Ransom] admitted that the industrial mind displayed 'almost miraculous cunning,' it was, he urged, 'rightly a menial': 'It needs to be strongly governed or it will destroy the economy of household" (idem: XXXIX).

The 1940s saw the end of the I'll Take My Stand Agrarians' project and in 1945 John Crowe Ransom acknowledged that their principles would not succeed in making America go back to the simpler good agrarian values that characterized her past. Yet, as Freyfogle declared in 2001, "it is as unsurprising as it is heartening that agrarian ways and virtues are resurging in American culture, prompted by a wide range of public and private ills. To the diseases and degradations of the modern age, a New Agrarianism is quietly rising to offer remedies and defenses, not just to the noise, vulgarity and congestion that have long affronted urban dwellers but to various assaults on land, family, religious sensibilities and communal life that have tended everywhere to breed alienation and despair" (idem: XIV). Along the same lines, the writer, poet, New Agrarian cultural critic, and farmer Wendell Berry remarked in 2002 in "The Agrarian Standard" that, "In [this] time it is useless or wrong to suppose that a great many urban people ought to go out into the countryside and become homesteaders or farmers. But it is not useless or wrong to suppose that urban people have agricultural responsibilities that they should try to meet. And in fact, this is happening." (Berry 2004: 150). He himself has taken on these responsibilities by establishing a small farm near Port Royal, Kentucky, by sustainably working his land and writing his texts for about five decades. Indeed, as Freyfogle predicted in 2001, "With no fanfare, and indeed with hardly much public noise, agrarianism is again on the rise" (idem: XIII). To oppose the degradation of a sustainable and healthy way of life, a New Agrarian Movement in American Culture has been propounded by representative figures such as Wendell Berry, who, as he himself acknowledges, is heir to some of the principles of I'll Take My Stand (see Carlson 2007: 96). Thus, while Berry denounces in "The Whole Horse" that, 
"[w]hereas industrialism is a way of thought based on monetary capital and technology, agrarianism is a way of thought based on land" (Berry 2001: 67) at the same time he also problematizes the importance of understanding the connection between food and land as unquestionable bases for a good life.

As one of the New Agrarians of today, gathered in The New Agrarianism: Land, Culture and the Community of Life, Berry longs for and defends the rebirth of agrarian practices and values at the same time as he tries to update them. He thus resembles both his spiritual father John Crowe Ransom, who defended in "Reconstructed but Unregenerate" that a happier human destiny should be secured through "an honorable peace with nature" (Ransom et alli: 1977: 7) and Robert Penn Warren, who warned against the effects of industrialism and materialism (Ransom et alli: 246-264). However, Wendell Berry, like his New Agrarians fellows, yearns for a current agrarian revival, not only within a particular region but above all within a multiregional America. Indeed the New Agrarians try to articulate, as Gene Logsdon states in "What Comes Around," "the best of urban life with the best in rural life in a new admirable agrarianism" (Longsdon 2001: 89). In addition, while the Agrarians in 1930 looked forward to defending and affirming their own region in the context of the nation, embodying a discontent accumulated by a significant part of the South, the New Agrarians of our days are often concerned not only with land use and the industrial system around agriculture but also with food, since they highlight, as Steve McFadden refers, that "our food arises from agriculture, which arises from the land, which is essential to our survival [and] when this web of life is threatened - as it is now - we are in peril" (McFadden 2011: 33). Thus, they have undoubtedly given their contribution to the quest, so urgent nowadays, for a healthier and more ideal diet and a more balanced and happier world.

By the 1970s, a new community of intellectuals and writers began to gather around Wendell Berry, who for fifty years has been working his land on his small farm and writing his texts to preserve and defend the recovery of the purity of the food we eat. This Southern writer, poet, and farmer is, in fact, one of the most referred and quoted enthusiastic representatives of the New Agrarians of today, as he has been drawing attention to the fact 
that the industrialization of the food chain and the detachment from the land and agriculture are deeply interconnected. These two factors are part of the same principles and values that developed countries, and the United States in particular, live by nowadays. As a matter of fact, Berry has spoken in defense of local agriculture and of the need for reducing resource consumption as a way to rethink our society and the pleasures of eating.

Since his 1977 book, The Unsetting of America: Culture and Agriculture, Wendell Berry has indeed strongly argued against industrial agriculture while at the same time warning against the destructive action of industrialism and technology. Through his texts and his oral interventions, he has given enlightened contributions to the debate on the environment as well as on the questioning of current sustainable food in the United States, seeking to improve the natural and the modern human world by merging the best of the two. Looking at his body of work, we undoubtedly realize that Berry advocates an agrarian perspective to achieve a healthier and happier society leading to a renewed better world, while prophetically warning, ever since the 1970s, against the dystopian dangers the developed world is facing today, namely the current "environmental crises" and the "epidemic" of obesity and type 2 diabetes (see Berry b 2009 : XII).

“The discussion about food doesn't make any sense without discussion at the same time of land, land use, land policy, fertility maintenance, and farm infrastructure maintenance. How are you going to get the best farming and the best food from a landscape that has removed its fences, which means the animals have been removed from agriculture? Without animals, something essential is removed from the minds of the farmers. Corn and bean people, I'm afraid to have extremely specialized minds" (Leonard 2012: <https://www.dissentmagazine.org/article/nature-as-an-ally-an-interview-with-wendellberry>), Wendell Berry stated more recently, thus reaffirming what he had already written in 1989 in "The Pleasures of Eating", i.e., that "eating is an agriculture act" (Berry 2009a: $<$ https://www.ecoliteracy.org/article/wendell-berry-pleasures-eating>). This is Berry's "signal contribution to the rethinking of food and farming under way today" (Berry $2009 \mathrm{~b}$ : XIV), as stated by Michael Pollan, an American food journalist, a thinker on the issue of eating, an activist and professor of journalism at the University of California, who has 
written extensively in defense of eating well. Undoubtedly, discussing about and crusading for healthy food must mean, anywhere in the world, discussing the health of the soil, plants and animals, since, as eaters, we are definitely linked to agriculture, which, on the other hand, makes us question where our food comes from and how it is produced; it must mean thinking about the food we eat and denouncing, as Berry persuasively states, "what is wrong with the industrial food production systems, and that includes farming" (Leonard idem).

Intertwining food, culture and politics, Berry points out that "the industrial eater is, in fact, one who does not know that eating is an agricultural act, who no longer knows or imagines the connections between eating and the land, and who is therefore necessarily passive and uncritical - in short, a victim. When food, in the minds of eaters, is no longer associated with farming and with the land, then the eaters are suffering a kind of cultural amnesia that is misleading and dangerous" (Berry a idem). For this writer, eating has indeed social and political implications. As one of the forerunners of a national debate on food, eating, and farming, together with other essayists, such as Frances Moore Lappé and Joan Gussow, Wendell Berry began this discussion in the 1970s. His pivotal contribution led to a more profound debate on the question of the origins of the food Americans (and the western world in general) eat and to a critical reassessment of the American food system.

Michael Pollan, one of the most active proponents of the food reform in the United States, has stressed Berry's strong contribution to the debate about Americans' place and role within their food system. Indeed Berry has maintained that eaters must be aware that they are not passive consumers of food and most of the times they end up contributing to the system itself, often supporting a food industry based on money and lobbies' convenience, which hides the dangerous truth about industrialized food. In his introduction to Berry's Bringing It to the Table: On Farming and Food, Pollan stresses the great relevance of this writer, who, in spite of not being directly committed to a particular food movement, is someone who has inspired the rise of Food and Slow Food Movements in the United States (see Berry 2009b: IX-XVI).

"Americans today are having a national conversation about food and agriculture that 
would have been impossible to imagine even a few short years ago. To many Americans it must sound like a brand-new conversation, with its bracing talk about the high price of cheap food, or the links between soil and health, or the impossibility of a society eating well and being in good health unless it also farms well", states Michael Pollan in "Wendell Berry's Wisdom", stressing that if people are finally talking about food in the United States, it is because, in the 1970s, Wendell Berry began to problematize American agriculture, the way Americans feed themselves and politics of food itself (Polann 2009).

At the very beginning of this century, in "The Agrarian Standard", Wendell Berry denounced once more that, "industrialism cannot understand living things except as machines, and can grant them no value that is not utilitarian, it conceives of farming and forestry as forms of mining; it cannot use the land without abusing it. (...). It thus continues the economy of colonialism" (Berry 2004: 144). Yet, in this same essay, Berry enthusiastically states that the "agrarian population [in the United States] is growing, and by no means is it made up merely of some farmers and some country people. It includes urban gardeners, urban consumers who are buying food from local farmers, organizers of local food economies, consumers who have grown doubtful of the healthfulness, the trustworthiness and dependability of the corporate food system - people, in other words, who understand what it means to be landless" (idem: 150). Berry's life as an agrarian writer, as he himself stated in 2002, is "in such a time an odd experience" (idem: 143). However, this American intellectual and writer remains today as hopeful for the future as he then declared:

One keeps writing essays and speeches that one would prefer not to write, that one wishes would prove unnecessary, that one hopes nobody will have any need for in twentyfive years. My life as an agrarian writer has certainly involved me in such confusions, but I have never doubted for a minute at the importance of the hope I have tried to serve: the hope that we might become a healthy people in a healthy land (Ibidem). 
Actually, Berry is known to many as a great inspiring reference to sustainable food movements in the United States, having thus greatly contributed to the Food Studies programs in American higher-education institutions which started to crop up in the period around the 1990s. Nevertheless, Berry's work and thought can be truly understood and appreciated only if we recognise the undeniable utopianism which has been feeding his hopeful prospect of an organized and well-structured agrarian society, where all might eat sustainably. As a matter of fact, if the connection between healthy and sustainable food and sustainable land was already degraded in 1989, as Berry fiercely denounced in "The Pleasures of Eating," what then to say in 2017? To this question, Wendell Berry enthusiastically keeps answering that hope is a virtue (see Baker/Bilbro 2017: 192).

\section{Works Cited}

Berry, Wendell (1996), The Unsettling of America: Culture and Agriculture, San Francisco, Sierra Club Books [1977].

-- (2001), "The Whole Horse", in The New Agrarianism: Land, Culture and the Community of Life, Washington D.C., Island Press, 63-80.

-- (2002), "The Agrarian Standard", in Citizenship Papers: Essays by Wendell Berry, Washington D.C., Shoemaker \& Hoard, 143-152 [2003].

-- (2004), Citizenship Papers: Essays by Wendell Berry, Washington D.C., Shoemaker \& Hoard [2003]. 
-- (2009 a), "The Pleasures of Eating", <https://www.ecoliteracy.org/article/wendell-berrypleasures-eating> (last accessed 5/4/2017 [1998] (last accessed 5/4/2017).

-- (2009 b), Bringing it to the Table: On Farming and Food, Berkeley, Publishers Group West. Bilbro, Jeffrey/jack R. Baker (2017), Wendell Berry and Higher Education: Cultivating Virtues of Place, Kentucky, University Press of Kentucky.

Carlson, Allan (2007), "Wendell Berry and the Twentieth-Century Agrarian 'Series'”, in Wendell Berry: Life and Work, Kentucky, University Press of Kentucky, 96-111.

Conkin, Paul K. (1988), The Southern Agrarians, Knoxville, The University of Tennessee Press.

Freyfogle, Eric T. ed. (2001), The New Agrarianism: Land, Culture and the Community of Life, Washington D.C., Island Press.

-- (2001), "A Durable Scale", in The New Agrarianism: Land, Culture and the Community of Life, Washington D.C., Island Press, XIII-XLI.

Leonard, Sarah (2012), "Nature as Ally: An Interview with Wendell Berry", $<$ https://www.dissentmagazine.org/article/nature-as-an-ally-an-interview-with-wendellberry> (last accessed 5/4/2017).

Logsdon, Gene (2001), "What Comes Around", in The New Agrarianism: Land, Culture and the Community of Life, Washington D.C., Island Press, 82-92.

McFadden, Steven (2011), The Call of the Land: An Agrarian Primer for the 21th Century, Martinsville, NorLights Press. Com.

Peters, Jason ed. (2007), Wendell Berry: Life and Work, Kentucky, University Press of Kentucky.

Pollan, Michael (2009), "Wendell Berry's Wisdom", <http://michaelpollan.com/articlesarchive/the-nation-magazine-wendell-berrys-wisdom> (last accessed 5/4/2017).

Ransom, John Crowe (1934), “The Aesthetic of Regionalism". American Review, 2, 290-310. 
Ransom, John/Donald Davidson/Frank Lawrence Owsley (orgs.) (1977), I'll Take My Stand: The South and the Agrarian Tradition, Baton Rouge, Louisiana State University Press [1930]. Ransom, John Crowe, "Reconstructed but Unregenerate", in I'll Take My Stand: The South and the Agrarian Tradition, Baton Rouge, Louisiana State University Press, 1-27 [1930]. Warren, Robert Penn. "The Briar Patch", in I'll Take My Stand: The South and the Agrarian Tradition, Baton Rouge, Louisiana State University Press, 246-264 [1930].

Maria Teresa Lobo Castilho obtained her PhD in American Literature in 1996, with a dissertation entitled Visões do Sul na Ficção Longa de Eudora Welty: "Outra (?) Terra, Outra (?) Literatura." She is Associate Professor at the Faculty of Letters of the University of Porto. She is a full member of CETAPS (Centre for English, Translation and Anglo-Portuguese Studies), she collaborates with ULICES (University of Lisbon Centre for English Studies) and she is Chair of APEAA (Associação Portuguesa de Estudos Anglo Americanos) General Assembly Border. Maria Teresa Castilho has published essays on American Literature and Culture, Southern Studies, Utopian Studies and Film Studies, and more recently on Food Studies. 